\title{
Business Strategy of Indah Kiat Pulp and Paper Perawang Mill, Riau, Indonesia using PESTLE, Porter's Five Forces, and SWOT Analysis under SOSTAC ${ }^{\circledR}$ Framework
}

\author{
Gery Azhari Putera ${ }^{1}$, Jerry Heikal ${ }^{2}$ \\ 1,2Magister Management Department, University of Bakrie, Jakarta, Indonesia \\ *Corresponding Author geryazhari@gmail.com
}

\begin{abstract}
Article Info

Volume 8, Issue 6

Page Number : 252-270

Publication Issue

November-December-2021

Article History

Accepted : 15 Nov 2021

Published : 30 Nov 2021

According to the company annual report (INKP Annual Report, 2019), PT. Indah Kiat Pulp and Paper (INKP) experienced a decrease in net sales of $3.4 \%$ and net profit of $53.4 \%$ from the previous year. The decline was followed by the Covid-19 pandemic which could affect the company's sales and profits. The study was conducted using a descriptive approach in order to capture the phenomena that occur through analysis of current conditions both internal and external using PESTLE, Porter, and SWOT analysis. Afterwards, it formulates the company objective, strategy, tactics, action, and evaluation or control using the SOSTAC ${ }^{\circledR}$ framework based on the analysis result. Data are obtained from interviews, observations, documentation, and publication reports.

The results of the research describe that the predominant internal strategy factors on the Strengths of INKP are the product quality and production process efficiency, and the Weaknesses are product distribution and its distribution channels. Meanwhile, the predominant external strategic factors on Opportunities are other needs in pulp derivative product, availability of raw materials and fiscal policy, and as for Threats are a decrease in fine paper demand and technology adaptation. Using the Cartesian SWOT diagram, it is found that the results of EFAS and IFAS are in the ST main strategy quadrant, which is Diversification. Based on the results of the analysis, it can be formulated that the objectives of the INKP strategy are to make diversification product such as rayon fiber with masks as the final product from pulp as the raw materials in 1 year and shifting production from $56 \%$ paper and $43 \%$ pulp to $45 \%$ paper, $34 \%$ pulp, and $20 \%$ rayon fiber in 3 years to maintain sales volume and gain increased profit. The corporate level strategy is a diversification product while the business level strategy is a differentiation product in accordance with Porter's Generic Matrix. This investment has a positive value of both CAPM and NPV while CAPM has 0.0708 value. As for the IRR, the rate of return is $39.87 \%$. Planned tactics and actions using project management with Gantt Chart within a project period of 1 year in the main activities of building production lines and marketing. Control and
\end{abstract}


evaluation are carried out through the implementation of targets or KPI in accordance with work functions. EBIT and EBITDA is used at the final level of overall production and marketing.

Keywords: PESTLE, SWOT, SOSTAC, Strategy, Business

\section{INTRODUCTION}

Company performance in 2019 was below the initial target comparing to the stipulated target in the previous year in accordance to the published annual company's report. The Net Profit was decreased for 3.4\%. Global market is becoming more competitive with is accelerated by economic distress, trade war, volatility of currency, and decreasing of market's growth.

According to Soewardjono (2005), profit is an indicator of the efficiency of using company funds in the realization of the rate of return on investment, an indicator of measuring company performance, the basis for distributing dividends, the basis for distributing employee bonuses, determining tax costs, and as a controlling tool for debtors in debt contracts. The increase or decrease in sales and profits will affect all stakeholders and shareholders. Therefore, the company's financial statements are used as a communication tool to investors and all parties involved.

INKP is one of pulp and paper company under Sinar Mas Pulp and Paper business unit that distributes their product to more than 150 countries around the world. INKP in particular produces pulp, cultural paper product, industrial paper, and tissue to both domestic and export market. In domestic market, INKP is known to produce Multipurposes paper using SiDU Brand which is cover up to $60 \%$ of market share. Besides that, around $80 \%$ in 2019 of the total domestic market's products from INKP is SiDU paper.
This brand directly associates to its producer which is INKP. The domestic market's net profit is also decreasing in line with the overall net profit in accordance to the annual company's financial statement 2019.

According to Kotler (2008), the decline in sales and profitability is influenced by price. Price is one of the important factors in determining market share and company profits. In the marketing mix (Shinta, 2011), sales can be increased by increasing consumer demand by implementing the right strategy in promotion, price, product, and place.

In these factors, price is the only factor that generates revenue and affects sales. In addition to the price factor, according to Porter (2008), competitive advantage is one of the factors that can provide competitiveness to survive in the industry.

In following to the above phenomenon, it is needed to analyze the current situation both internal and external of the subject focus. This data will be interpreted using SWOT Analysis to determine the theoretical business strategy. Therefore, the Authors is keen to bring up this phenomenon to be one of the research subjects.

\section{A. PESTLE Analysis}

PESTLE analysis is a structure for planning, presenting and writing reports, it is also an analytical tool for considering external factors and assisting in impact analysis. PESTLE is primarily used to identify 
and summarize environmental influences on an organization to help assess it in its actual and future strategic context. Apart from that, it is also a useful tool for understanding the external macro environment involved. PESTLE helps organizations actively adapt to a changing environment and enables forward thinking so problems can be anticipated.

PESTLE analysis can help take advantage of opportunities and minimize threats. PESTLE can help avoid strategies that may fail for reasons beyond our control or external. This PESTLE analysis itself is consist of Political, Economy, Socio-cultural, Technology, Law, and Environment.

\section{B. Porter's Analysis}

Porter's analysis is used to analyze the competitive environment that affects an industry and its marketing. This analysis provides knowledge about the competitive advantages that exist today and will be faced in the future. Companies can increase their strengths and anticipate weaknesses so that they can avoid companies from making wrong decisions. According to Porter (2008) in the Harvard Business Review, competitive advantage determines the profitability of a company and is also an important part of determining the company's strategy. Competitive analysis is obtained from the results of an analysis of the combination of the five competitive forces or known as Porter's Five Forces, namely:

- Competitive Rivalry within the Industry

- Threat of New Entrants

- Threat of Substitutes

- Bargaining Power of Suppliers

- Bargaining Power of Buyer

\section{SWOT Analysis}

SWOT analysis is the identification of various factors systematically to formulate corporate strategy. This analysis is based on observations to maximize strengths and opportunities, but simultaneously minimize weaknesses and threats. Strengths and opportunities come from within the company which are things that can be controlled and changed. Weaknesses and threats are things that are external but can affect the business or things that can happen beyond the control of the company.

The main purpose of SWOT analysis is to help companies understand all the factors involved in making business decisions. Strategic decision making will be related to the mission, goals, strategies, and policies of the company itself. Or in another sense, SWOT analysis is an analysis of current conditions for understanding and consideration in strategic decision making (Rangkuti, 2019).

\section{Management Strategic}

Strategy formulation is an important stage in achieving company goals. Each organization or company will formulate a different strategy, according to their respective goals and conditions. Corporate strategy is a comprehensive planning formulation of how a company achieves its mission and goals. Strategic planning is summarized in a strategic management. According to Jauch and Glueck (1999), strategic management is a number of decisions and actions that lead to the preparation of a strategy or a number of effective strategies to help achieve company goals. The strategic management process is the way strategic planners set goals and make decisions.

Strategic management is the art and knowledge of formulating, implementing and evaluating crossfunctional decisions that make an organization achieve its goals. The strategic management process consists of three stages: strategy formulation, strategy implementation and strategy evaluation. 
Strategic management is about gaining and maintaining a competitive advantage. This terminology is defined as anything that a company does very well compared to its competitors. When a company can do something and another company can't, or has something its competitors want, it represents a competitive advantage.

\section{E. Competitive Strategy}

Competitive strategy is to connect the company with its environment. Although the relevant environment is very broad, encompassing social forces as well as economic forces, the main aspect of the corporate environment is the industry in which the company competes.

Competition is at the core of a company's success or failure. Competition determines the feasibility of a company's activities that can contribute to its performance, such as innovation, a cohesive culture, or good implementation. Competitive strategy is an effort to find a competitive position that can benefit the company in an industry, the search for fundamental areas where competition occurs. Competitive strategy aims to build a profitable and sustainable position against the forces that determine industry competition (Porter, 1985, p. 1).

Each of the generic strategies involves a fundamentally different route to competitive advantage, combining choices about the type of competitive advantage explored with the scope of strategic objectives for achieving competitive advantage. Cost leadership and differentiation strategy seek competitive advantage in various industry segments, while the focus strategy refers to cost advantage or differentiation in a narrower segment (Porter, 1985, p. 11).

\section{F. Business and Corporate Level Strategy}

Corporate strategy handles the entire strategic scope of the company, especially in determining the goals and objectives of a company. This strategy is needed to determine what business the company should or want to have such as the type of product to be produced and where the product should be marketed. Corporate Level Strategy also determines the direction that the company will go and the role of each business unit in the company to achieve that direction.

There are two important things that must be done at the corporate level strategy, namely:

- Establishing the Vision and Mission of the Company

- Determine the Objectives of the Company

There are three types of strategies that can be used at this strategy level, namely:

- Growth strategy

- Stability strategy

- Retrenchment strategy

\section{METHODS}

This research is a qualitative research with a descriptive approach where the purpose of the study is to describe the phenomena that occur and the factors that influence these phenomena. This will give researchers a basis for providing alternative strategies to solve the problems faced by the object of research.

Descriptive research is a research method aimed at describing existing phenomena (Hamdi \& Bahruddin, 2014). According to Morissan (2012), Descriptive Research aims to explain a certain social condition by observing the object of research. Descriptive research also pays attention to the actual problem solving when the research is carried out. 


\section{A. Data Collection}

Based on the source, the research data that will be used in this study are:

1. Primary data is data obtained or collected directly from the data source. The technique that will be used by researchers to collect primary data is observation and interviews.

The process of collecting data through observation can be done by observing the market, target market, and company resources. Interviews will be conducted with several employees of the company who have work responsibilities and knowledge of the object of research. The interview method will be conducted using semi-structured interview guidelines, namely a series of questions will be compiled and one by one and deepened as needed until all variables are answered in depth (Siyoto and Sodik, 2015).

2. Secondary Data is data obtained or collected from various existing sources or documentation (Siyoto and Sodik, 2015).

The secondary data can be obtained from the documentation of published reports such as annual reports and quarterly financial reports in 2020. Other secondary data are company profiles, product brand profiles, publications of scientific bulletins from the association of Indonesian paper companies, publications of scientific articles, business reports and business development news publication.

\section{B. Research Instrument}

To obtain answers to the objectives of this study, the research instrument used was open-ended questions which were formulated, examined, and considered with the supervisor. These questions will be conducted through an interview process.
Open-ended questions that have been prepared will be asked through an interview process with a semistructured method where structured questions will be asked at the beginning of the interview and followed by questions that will deepen and obtain further information (Siyoto and Sodik, 2015).

\section{Data Analysis Method}

The research method used is descriptive qualitative analysis which is carried out continuously from the beginning to the end of the research by inductive, and looking for patterns, models, themes, and theories. According to Hardani, et al. (2020), qualitative data analysis is the process of systematically searching and compiling data obtained from interviews, field notes, and documentation. Analysis according to Miles and Huberman, 1992 in Hardani, et al. 2020, divided into three streams of activities that occur simultaneously. The three streams are:

- Data Reduction

- Data Presentation

- Withdrawal of Conclusions

\section{RESULTS AND DISCUSSION}

A. PESTEL analysis - Current External Situation PESTEL analysis is used as a tool to monitor the environment around INKP at a macro level where INKP operates and markets its products. The year 2021 cannot be separated from the impact of the Covid-19 pandemic that emerged in early 2020. The government has issued so many policies that aim to provide conducive conditions for the people and other stakeholders, including the industrial world. The global pandemic period began when the World Health Organization (WHO) on March 11, 2020 stated that the world was experiencing a Global Pandemic Corona Virus Disease-19 (Covid-19). This condition is considered a very new condition for the world, including Indonesia, so that new policies have 
emerged that have an effect on economic conditions, both macro and micro.

\section{Politics}

Situmorang (2009), explains that political stability is a very important factor in business and industry. Unstable political conditions can have a negative impact on business and industry. Elections and changes from presidents to members of state parliaments can have an influence on businesses, especially those related to investment. Indonesia has a 5 -year cycle for presidential and legislative elections which were held in 2019. According to the Indonesian General Elections Commission, in 2020 the elections for regional heads (Governor and Mayor/Regent) were carried out successfully and very well. According to Komarudin (2021), Indonesia's political projections in 2021 will not experience many political events. The absence of elections and local elections makes 2021 relatively conducive and politically stable.

Indonesia's fiscal policy in 2021 is based on a release from the Indonesian Ministry of Finance (2021), which focuses on accelerating the national economic recovery program and continuing structural reforms. Economic recovery carried out by the government is also prioritized by strengthening the domestic economy so that it is more resilient and competitive. Structural reforms will be carried out by continuing the program to improve the investment climate and economic competitiveness, as well as improving the quality of human resources to increase productivity through education and health policies. Next is reform in the state revenue sector, both on the tax side, nontax state revenue (PNBP), as well as on fiscal transfer policies. Then, improving the quality of state spending and improving long-term fiscal sustainability are also part of the budgeting reform program. And, accelerating national development with development priorities in health sector reform, education reform, infrastructure, information technology and national food security.

The fiscal policy has steps that are implemented with the birth of several tax policies. Article 22 relaxation of import taxes, through this policy it is hoped that the industry will get cash flow space as compensation for transfer costs (costs related to changes in the country of origin of imports and export destinations). In addition, by changing the country of export destination, it is expected that exports will increase. Income Tax Article 25 which will receive incentives by reducing the number of installments.

\section{Economy}

Data from the Central Statistics Agency reported that Indonesia's economic growth contracted by $2.19 \%$ in the fourth quarter of 2020, 3.49\% in the second quarter, and $5.32 \%$ in the second quarter on a year on year basis. Meanwhile, cumulatively in 2020, Indonesia's economic growth rate is $-2.19 \%$ (yoy). This decline is one indicator of a decline in economic activity such as reduced employment, average income, investment and corporate profits. This condition brought Indonesia to a state of economic recession where gross domestic economic growth decreased in 2 quarters or for 6 months as explained by the Indonesian Minister of Finance, Sri Mulyani in a release of the Ministry of Finance, 2020.

The economic recession has an impact on the decline in people's income and changes in purchasing behavior. People tend to buy basic needs compared to other expenses. The impact of the economic recession can also be felt by companies with a decline in corporate profits and demand in the market. Therefore, the condition of the Indonesian economy may have a negative impact on the demand for INKP paper products.

\section{Socio-cultural}


Sociocultural changes in Indonesia are inseparable from the emergence of policies during the global pandemic. The government is campaigning for changes in social behavior such as social distancing and restrictions on people's mobility. The homecoming culture has also changed in line with government recommendations and policies to prevent the spread of the Covid-19 virus. Furthermore, this policy will also have an impact on the world of education in Indonesia with the implementation of online learning through technological media. This application reduces face-to-face learning so that direct social activities are reduced. Likewise with the world of work that implements the policy of working from home or Work From Home (WFH).

Sociocultural changes in Indonesia have an impact on the reduction of social activities between individuals directly. Technology gives a greater role to the community's freedom to implement these policies. From the point of view of paper producers where their market share is offices and schools, the changes and implementation of this policy result in a reduction in the demand for paper products. Paper is one of the commodities that are needed and used in daily learning in schools and offices.

The government's policy in preventing the spread of Covid-19 is the use of masks in public spaces. According to the Ministry of Industry (2021) in a press release, the need for N95 masks throughout 2021 is projected to reach 11 million pieces, while the domestic production capacity of N95 masks is estimated at 3 million pieces per year. Therefore, it is necessary to take steps to accelerate the production of N95 masks to meet national needs and optimize the absorption of domestic medical mask products, both in the form of domestic and export absorption. Another strategy in an effort to accelerate the production of N95 masks is to provide facilities for implementing quality standards for N95 mask products that are easily accessible to domestic industries.

\section{Technology}

According to E.P Saputro (2020), the rapid development of technology has changed the global economic order towards a digital economy. During this global pandemic, online transactions continue to grow rapidly coupled with social distancing policies and working from home. Digitization has changed many forms of community activity, starting from the search for classic information media which used to be in the form of print media to become more recent media on digital portals with very fast updating rates. In the world of education, students do not have to bring printed books because digitization makes it easy with the availability of e-books or electronic books. Many higher-level educational institutions apply paperless or paperless policies in daily learning activities. This shift can have a negative impact on paper producers by emerging substitute products in the form of digitalization technology.

\section{Environment}

The paper and pulp industry require wood as the main raw material. According to the Trade Assessment Report (2016), Indonesia has vast potential for industrial forest plantations (HTI). Indonesia's geographical location also supports and becomes one of the advantages in the development of the paper and pulp industry.

Problems regarding the environment, especially forests, surfaced with a deforestation rate of $30 \%$ in the 2014 - 2015 period which occurred in forest and land fire areas according to the Indonesian Ministry of Forestry / Ministry of Forestry (2019). The year 2014 was one of the years when forest fires in Indonesia reached a very wide level that attracted the attention of neighboring countries such as Singapore 
and Malaysia. Forest fires occurred in several provinces in Indonesia such as Riau, South Sumatra and several areas on the island of Kalimantan.

The Indonesian Ministry of Forestry and various parties collaborated with the launch of the Paper Legality Verification System (SLVK). Paper can be said to be legal after all procedures and requirements such as logging, logging permits, processing, trading, and the origin of paper can be proven to meet all applicable legal requirements. The main function of the SLVK is to ensure that the entire production process from raw materials to processing and management meets the applicable legal aspects. This system then provides legal certainty for Indonesian paper products in the global market so as to increase competitiveness.

INKP cooperates with the parent company to maintain compliance with the laws and regulations in Indonesia regarding Industrial Plantation Forests and Indonesian Legal Wood certification through SLVK which is also an international standard to maintain compliance with legality. INKP and companies engaged in forestry always protect forests by only using raw material sources from HTI and replanting. Wood is a renewable source of raw materials. With experience and advanced agricultural technology, trees can be harvested over a period of time to maintain the demand for pulp and paper production. In addition, INKP also has several certifications such as PEFC (Programme Endorsement of Forest Certification) on an international scale and nationally with IFCC (Indonesian Forestry Certification Cooperation) regarding forest management certification schemes. PEFC is the largest forest certification system in the world by the number of certificates issued. PEFC is the international environmental label of choice for responsible forest management. Forest certification ensures that forests are managed according to environmental, social and economic criteria. PEFC certification makes it possible to trade PEFC certified paper products or processed paper products in the market. Many public and private procurement policies require or prefer PEFC certified materials (PEFC.org, 2020).

For forest fires, INKP and partner companies form a task force to protect forests in the area of operation. Several Towers of View were erected to watch over the forest. The drainage system is built to prevent the spread of fire from one area to another and establish an integrated extinguishing method.

\section{Law}

Based on the Coordinating Ministry for Economic Affairs of the Republic of Indonesia (2021), on October 5, 2020, the Law on Job Creation (UU CK) was passed which was registered as Law No. 11 of 2020 concerning Job Creation by the Indonesian House of Representatives. The CK Law aims to create jobs and increase foreign and domestic investment by reducing regulatory requirements for business permits and land acquisition. Several parts of the CK Law provide changes to employment in Indonesia such as wages and working hours as well as regulations regarding foreign workers. In addition, it also regulates taxation on $\mathrm{PPh} 25$ for companies, regarding the environment, investment, and so on.

The creation of the Job Creation Law can have a positive potential impact on the company through relaxation of wages and working time arrangements that are part of the company's fixed costs. However, the actual implementation of the CK Law cannot be ascertained because it is relatively new so it takes time to be socialized and implemented by the company through the company's internal policies and regulations.

\section{B. Porter's Analysis - Current Internal Situation}

INKP certainly has a competitive advantage to be able to compete with competitors and compete and win the market. According to Porter (2008) in the 
Harvard Business Review, competitive advantage determines the profitability of a company and is also an important part of determining the company's strategy. Competitive analysis is obtained from the results of an analysis of the combination of five forces or known as Porter's Five Forces.

\section{Competitive Rivalry within the Industry}

Industry in this competitive intensity according to Porter (2017) is a group of companies that produce products that can replace each other within geographic market boundaries. For the domestic market (Indonesia), several products can be easily found at retailers under several brands such as SiDU, Bola Dunia, PaperOne, Natural, ePaper, Kiky, and so on. Of these various brands, paper producers have turned to several companies or business groups, namely Asia Pulp Paper (APP) which consists of Indah Kiat Perawang Mill (INKP) and Pindo Deli Karawang (PD), Riau Andalan Pulp Paper (RAPP) which is part of from April Group, and Solo Pure.

\section{Threat of new Entrants}

Indonesia has abundant natural resources to support the growth of the pulp and paper industry based on the Trade Assessment Report (2016). Indonesia has potential, especially related to raw materials, with plant productivity in Indonesia being higher than competing countries with subtropical climates. Therefore, the potential for the emergence of new paper producers is huge. Based on the Indonesian Pulp and Paper Association (2019), there are 84 companies that produce pulp/paper pulp which is the raw material for making paper. The threat of new entrants from a product that has great potential comes from raw material producers who extend their business chain for fine paper products or paper that can be grouped into printing and writing paper.

According to the Ministry of Industry (2019), the largest pulp producer in Indonesia is Asia Pulp and Paper (APP) with a cumulative production of around
6.5 million tons per year. The companies that are members of APP are Indah Kiat Perawang Mill in Riau with a capacity of 3 million tons of pulp per year, Lontar Papyrus in Jambi with a capacity of 1 million tons of pulp per year, and Oki Pulp \& Paper in South Sumatra with a capacity of 2.5 million tons of pulp. per year. Next is Riau Andalan Pulp \& Paper, Riau with a pulp production capacity of 2.5 million tons per year. And Toba Pulp Lestari in North Sumatra with a capacity of 185 thousand tons of pulp per year.

Based on the data collected, the threat of new entrants into the industry coming from paper or pulp raw material producers is very small. The dominant business group in the market is a business group that already has its own fine paper product and is actually competing in the market.

\section{Threat of Substitutes}

Based on the Central Bureau of Statistics (2018), the demand for paper has not decreased. In 2019, affected by government policies regarding the Covid-19 pandemic situation, the growth of paper could be threatened and replaced by technology that promotes the reduction of paper use, especially in the school and office market groups. However, based on data on paper sales, especially multipurpose paper, INKP did not experience a significant decline or could be said to be stable.

The threat of substitute goods in the form of technology shift does not pose much of a threat at this time as evidenced by the absence of a significant decline in sales. The domestic market which is filled with schools and offices consistently uses paper for their daily needs.

\section{Bargaining Power of Suppliers}

The paper industry is a derivative product of wood processing from industrial plantation forests into pulp or paper pulp. The bargaining power of suppliers becomes a threat for companies that have been 
dependent on certain suppliers. Suppliers can pose a threat to the industry through increasing product prices and decreasing product quality and product availability (Porter, 1987).

INKP is an integrated paper mill which has a supply chain from wood products to pulp processing. APP Sinarmas is a business group that has an integrated raw material supply chain where raw material sources can be obtained from other companies within the same business group such as Lontar Papyrus in Jambi and Oki Pulp and Paper in South Sumatra. Availability of raw material supply in the form of pulp can be guaranteed throughout the year. However, price increases can pose a threat to the company's margins in the production process which directly impacts price changes on the final paper product. Having integrated processing facilities, INKP can increase production efficiency and reduce intermediate and energy processing costs.

\section{Bargaining Power of Buyer}

The bargaining power of consumers is also higher when what is purchased is a common commodity product and is undifferentiated from one another. Therefore, the buyer will have consideration of the selling price and the quality or quality expected. Competitors can offer products that can be compared so that customer loyalty becomes a threat to the company. Then, brand value is also a reference for purchasing decisions in addition to price and quality (Foris and Mustamu, 2015).

Buyers of SiDU brand multipurpose paper are students, schools and offices. The demand for multipurpose paper from year to year does not have a significant growth or is stagnant. Changes in behavior for individual buyers do not have a significant impact because the main target market is schools and offices which cannot be separated from the need for paper for printing and photocopying as a medium for sharing information and reports.
Multipurpose paper product is a consumer product that can be easily found in the market without requiring more effort. In the market, buyers are faced with several product choices that generally do not offer specificity and uniqueness so that the power of buyers will be influenced by price, quality, and brand value. SiDU multipurpose paper based on data acquisition has a market share of $60 \%$ for the Indonesian domestic market. SiDU is one of the brands that sponsored the Asian Games in Indonesia in 2018, thereby increasing Brand Awareness in the eyes of buyers.

\section{SWOT Analysis}

\section{Strengths and Weaknesses}

Internal environmental analysis is an analysis by looking at the strengths and weaknesses of the company. The company's strengths can be used for development and become the main capital and core competencies in implementing business strategies. As for the weaknesses, it can be used as a guideline for improvement in order to be more competitive with competing companies. The strengths of INKP as a producer of multipurpose paper products are as follows:

\section{- Large Market Share}

The SiDU brand multipurpose paper has a market share of $60 \%$. With a dominant market share in the market, the SiDU brand can be said to be a market leader who will become a reference for other brands and brands with similar or the same products.

\section{- Better Product Quality}

The main strength of SiDU multipurpose paper is the quality of the product which has a good level of brightness and whiteness of the paper and physically thicker paper than competitors in the same grammage. Then, SiDU multipurpose paper guarantees better printing results with Trutone technology.

\section{- Raw Materials}


As one of the paper producers that has an integrated factory, INKP has the advantage of guaranteed supply of raw materials throughout the year. INKP is also part of the APP Sinarmas business group which has several pulp mills as the main raw material for paper which can support the maintenance of raw material supply.

\section{- $\quad$ Production Process Efficiency}

With integrated factory capabilities, INKP can increase the efficiency of the production process by eliminating the secondary process from pulp to paper. This process also maintains the stability of the quality of raw materials so as to provide a more maintained final paper product.

\section{- $\quad$ Lower Product Prices}

The price of SiDU multipurpose paper is relatively cheaper in terms of competing with its main competitor, PaperOne from APRIL for the same product. This price fixing can be achieved because production costs can be reduced by efficient production processes and more efficient use of energy.

In addition to having strengths, SiDU multipurpose paper also has weaknesses that can be used as a guideline for improvement in making business strategies in the future. The weaknesses are:

\section{- Product distribution.}

The distribution of SiDU multipurpose paper requires more attention due to the long distribution chain from Riau to Java Island where the demand for paper is very large. This process puts more effort into maintaining the quality level of the paper so that it is delivered in perfect condition without defects.

\section{- Distribution channel}

INKP generally has a sole distributor, namely CMI which is a member of the APP Sinarmas business group. Central corporate policy with this distribution channel provides a long supply chain down to the retail or buyer level. Sole distributors will sell products to authorized distributors who are geographically designated to cater to a particular market. In addition, distribution channels are also distinguished from business-to-business distribution channels.

\section{- Brand Promotion.}

With a fairly large market share, SiDU multipurpose paper provides little brand promotion at the national level. The promotions carried out have a regional scale with writing competitions for school students so that the scale of the promotion to increase Brand Awareness and Brand Acknowledgment is quite small.

\section{- Main raw material suppliers.}

Despite having a guaranteed supply of raw materials from internal business groups and an integrated production process, the increase in the price of the main raw materials is unavoidable. The increase in raw material prices will directly have an impact on sales margins and the final price of paper products.

\section{Opportunity and Threat}

The results of the analysis for Opportunity and Threat in this SWOT Analysis will refer to the analysis of external conditions using PESTLE analysis. The opportunities or opportunities owned by INKP are as follows:

- Fiscal Policy in Strengthening the National Economy

This fiscal policy includes relaxation of import taxes, incentives for $\mathrm{PPh}$ Article 25 and ease of exporting products from Indonesia. The government encourages Indonesia to become the country of origin for imports from the previous export destination. This policy also makes it easier to invest in Indonesia so as to give rise to other industries that can increase the number of Indonesian exports.

- Availability of Raw Materials: Industrial Plantation Forest 
Indonesia has abundant forest wealth. These resources have better economic value if they can be converted into products that have higher economic value. By encouraging Indonesia to become a country of origin for imports, the government makes it easy for investors to form industries that increase the value of export products. The ban on wood exports has also triggered the emergence of derivative products from industrial plantation forest products from Indonesia. Therefore, the government has established a legality certification body for forest products as one of the requirements to compete in the world of international trade and also to ensure that industrial activities meet good environmental management. This national certificate complements the international certification on forest and environmental management.

\section{- Changes in Community Behavior}

In socio-cultural terms, people are asked to maintain the spread of Covid-19 by maintaining distance, reducing mobility, maintaining cleanliness and using masks. One of the increasing markets demands during this pandemic is the increasing market demand for masks. The Ministry of Industry in a press release stated that the need for N95 masks in 2021 reached 11 million pieces while the domestic production capacity was 3 million pieces. The masks themselves are made of non-woven fabric raw materials which can be derived from semi-synthetic rayon fiber.

Then also threats that can have a negative impact on the company are:

\section{- Economic Recession Conditions}

The Central Statistics Agency reported that Indonesia's economic growth contracted by $2.19 \%$ in the fourth quarter of 2020,3.49\% in the second quarter, and $5.32 \%$ in the second quarter year on year. Meanwhile, cumulatively in 2020, Indonesia's economic growth rate is $-2.19 \%$ (yoy). This decline is one indicator of a decline in economic activity such as reduced employment, average income, investment and corporate profits.
The pandemic affects many things such as the economy and the behavior of society in general.

\section{- Decrease in Paper Demand}

The policies of working from home and studying from home led to a decrease in the demand for paper. Paper is often used in offices and schools as a physical form of using communication media in the form of reports, notes, and physical documents.

\section{- Technology Adaptation}

Policies to work from home and study from home also accelerate adaptation in the full use of technology. The physical form is being replaced by digitization.

\section{Matrix BCG (Growth-Share Matrix)}

Based on the data obtained, the market share or market share of INKP in the domestic market is $60 \%$ with a market growth of $6.70 \%$ in 2019 and $-2.14 \%$ in 2020. Using this data, the relative competitive position of INKP is $1.5 \mathrm{x}$ so that it can be plotted to in the BCG Matrix as below:

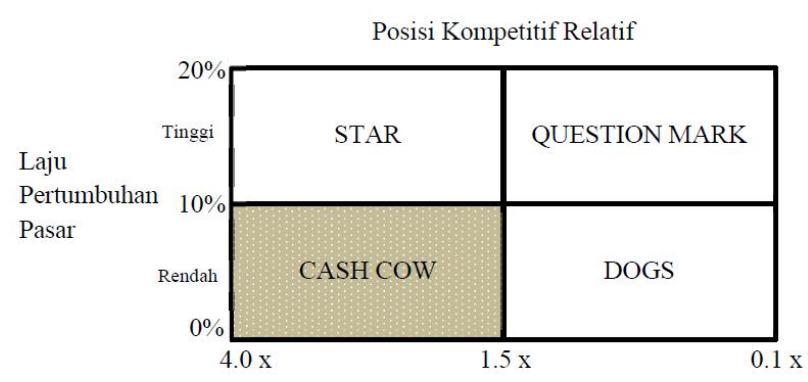

Picture 1 BCG Matrix of Relative Competitive Position

The Cash Cow position indicates that the market has matured. The growth rate is relatively low with the competitive level of the company in a relatively strong position so it is advisable to invest in Star or Question Mark positions (Rangkuti, 2019).

\section{Internal External Matrix}


The external internal matrix is the development of the GE matrix (GE-Model) with the parameters of the company's internal strength and external influences faced. This matrix aims to obtain a more detailed business strategy at the corporate level. Through data collection with resource persons as representatives of INKP, data were obtained for industry attractiveness factors and business strength factors.

Tabel 4.1 Industry Attractive Factor

\begin{tabular}{|c|l|c|c|c|}
\hline No. & Industry Attractive Factor & Weight & Rating & Score \\
\hline 1 & Market Size & 20 & 0.5 & 10 \\
\hline 2 & Market Growth & 30 & 0 & 0 \\
\hline 3 & Persyaratan Teknologi & 15 & 0.5 & 7.5 \\
\hline 4 & Kompetisi & 35 & 0.5 & 17.5 \\
\hline 5 & Pembatasan Secara Politis & 0 & 0 & 0 \\
\hline \multicolumn{2}{|c|}{ Total } & $\mathbf{1 0 0}$ & & $\mathbf{3 5}$ \\
\hline
\end{tabular}

Tabel 4.2 Business Strength Factor

\begin{tabular}{|c|l|c|c|c|}
\hline No. & Business Strength Factor & Weight & Rating & Score \\
\hline 1 & Market Share & 20 & 1 & 20 \\
\hline 2 & Kapasitas Produksi & 15 & 1 & 15 \\
\hline 3 & Efisiensi Produksi & 25 & 1 & 25 \\
\hline 4 & Lokasi Produksi & 10 & 0.5 & 5 \\
\hline 5 & Kemampuan Teknologi & 15 & 0.5 & 7.5 \\
\hline 6 & Pemasaran & 15 & 0.5 & 7.5 \\
\hline \multicolumn{2}{|c|}{ Total } & $\mathbf{1 0 0}$ & & $\mathbf{8 0}$ \\
\hline
\end{tabular}

The factors of industry attractiveness and business strength can be plotted in an internal external matrix to obtain a model for corporate level strategy.

\begin{tabular}{|c|c|c|c|}
\hline \multirow{2}{*}{$\begin{array}{l}\text { Industry's } \\
\text { Attractiveness }\end{array}$} & \multicolumn{2}{|c|}{ Business Internal Strength } & \multirow[b]{2}{*}{ Low } \\
\hline & High & Average & \\
\hline $\begin{array}{r}\text { Attractiveness } \\
\text { High }\end{array}$ & $\begin{array}{l}\text { 1. Growth } \\
\text { Concentrate through } \\
\text { Vertical Integration }\end{array}$ & $\begin{array}{l}\text { 2. Growth } \\
\text { Concentrate through } \\
\text { Horizontal Integration }\end{array}$ & $\begin{array}{l}\text { 3. Retrenchment } \\
\text { Turnaround }\end{array}$ \\
\hline Average & 4. Stability & $\begin{array}{l}\text { 5. Growth } \\
\text { Concentrate through } \\
\text { Horizontal Integration } \\
\qquad \quad \text { Stability } \\
\text { No changes needed } \\
\text { Profit Strategy }\end{array}$ & $\begin{array}{l}\text { 6. Retrenchment } \\
\text { Captive Company or } \\
\text { Divestment }\end{array}$ \\
\hline Low & $\begin{array}{l}\text { 7. Growth } \\
\text { Diversification } \\
\text { Concentric }\end{array}$ & $\begin{array}{l}\text { 8. Growth } \\
\text { Diversification }\end{array}$ & $\begin{array}{l}\text { 9. Retrenchment } \\
\text { Bankruptcy or } \\
\text { Liquidation }\end{array}$ \\
\hline
\end{tabular}

Based on the external internal matrix, the results in cell 7 are Growth, Concentric Diversification. This result is obtained from the industry attractiveness factor which is relatively low at 35 points and the internal business strength is relatively high at 80 points. According to Rangkuti (2019), a growth strategy is a strategy designed to achieve growth in sales, assets, profits or a combination thereof. This can be achieved in various ways such as developing new products, increasing product quality or increasing access to a wider market. In concentric diversification, the growth strategy is implemented when the attractiveness of the industry is low but the competitive position is very strong. Companies can create new products by utilizing their own strengths efficiently because the company already has the ability and good marketing with the principle of creating synergies from new products and old products in creating more profit than doing it alone.

\section{EFAS and IFAS from SWOT Analysis}

The results of the SWOT analysis are then assessed on internal and external factors through IFAS and EFAS to determine the main strategy for the company going forward. Table 4.3. IFAS describes the Internal factors through Strengths and Weaknesses which are then given a weighting and rating carried out by representatives from the Company.

\begin{tabular}{|c|c|c|c|c|c|}
\hline \multicolumn{2}{|r|}{ Strategic Factors } & Weight & Rating & $\begin{array}{l}\text { Weight } \\
\text { Score }\end{array}$ & Remarks \\
\hline \multicolumn{6}{|c|}{ STRENGTHS } \\
\hline $\mathrm{S} 1$ & Market Share & 0.09 & 3.00 & 0.27 & $\begin{array}{l}\text { Kertas Multiguna INKP } \\
\text { mempunyai market share } \\
\text { sebesar } 60 \% \text { di pasar domestik }\end{array}$ \\
\hline $\mathrm{S} 2$ & Kualitas Produk & 0.11 & 3.75 & $0.41^{*}$ & $\begin{array}{l}\text { Penggunaan wet pulp dapat } \\
\text { memberikan kualitas produk } \\
\text { yang lebih baik }\end{array}$ \\
\hline S3 & $\begin{array}{l}\text { Ketersedian Bahan } \\
\text { Baku }\end{array}$ & 0.09 & 3.25 & 0.29 & $\begin{array}{l}\text { Mempunyai pabrik yang } \\
\text { terintegrasi sehingga } \\
\text { ketersediaan bahan baku } \\
\text { terjamin. }\end{array}$ \\
\hline S4 & $\begin{array}{l}\text { Efisiensi Proses } \\
\text { Produksi }\end{array}$ & 0.11 & 3.50 & 0.39 & $\begin{array}{l}\text { Pabrik yang terintegrasi } \\
\text { memberikan keunggulan proses } \\
\text { produksi yang lebih efisien }\end{array}$ \\
\hline S5 & Harga Relatif Murah & 0.10 & 3.50 & 0.35 & $\begin{array}{l}\text { Efisiensi proses produksi dapat } \\
\text { mengurangi biaya produksi } \\
\text { sehingga harga jual dapat } \\
\text { ditekan tanpa menguragi margin }\end{array}$ \\
\hline & Sub Total & 0.50 & & 1.71 & \\
\hline \multicolumn{6}{|c|}{ WEAKNESS } \\
\hline W1 & Distribusi Produk & 0.13 & 3.50 & $0.46^{*}$ & $\begin{array}{l}\text { Letak lokasi pabrik dan regional } \\
\text { target yang jauh menimbulkan } \\
\text { biaya distribusi yang lebih besar }\end{array}$ \\
\hline W2 & Saluran Distribusi & 0.13 & 3.25 & 0.42 & $\begin{array}{l}\text { INKP menggunakan distributor } \\
\text { eksslusif dan regional agen } \\
\text { penjualan }\end{array}$ \\
\hline W3 & Promosi Brand & 0.12 & 3.00 & 0.36 & $\begin{array}{l}\text { Kurangnya Promosi Brand } \\
\text { mengakibatkan kurangnya } \\
\text { Brand Awareness di masyarakat }\end{array}$ \\
\hline W4 & Harga Bahan Baku & 0.12 & 3.00 & 0.36 & $\begin{array}{l}\text { Kenaikan harga bahan baku } \\
\text { harus diikuti dan diterima oleh } \\
\text { INKP dikarenakan keharusan } \\
\text { INKP untuk menyerap bahan } \\
\text { baku dari produksi mereka } \\
\text { sendiri }\end{array}$ \\
\hline & Sub Total & 0.50 & & 1.60 & \\
\hline & GRAND TOTAL & 1.00 & & 3.31 & \\
\hline
\end{tabular}

From the IFAS table above, it can be seen that the internal factors that become INKP's strengths are product quality with a weight score of 0.41 points. 
And the weakness of INKP is the distribution of products with a weight score of 0.46 points.

\begin{tabular}{|c|c|c|c|c|c|}
\hline \multicolumn{2}{|r|}{ Strategic Factors } & Weight & Rating & \begin{tabular}{|c|} 
Weighted \\
Score
\end{tabular} & Remarks \\
\hline \multicolumn{6}{|c|}{ OPPORTUNITIES } \\
\hline 01 & $\begin{array}{l}\text { Kebijakan Fiskal } \\
\text { Pemerintah }\end{array}$ & 0.16 & 3.00 & 0.48 & $\begin{array}{l}\text { Kemudahan investasi, relaksasi } \\
\text { pajak impor, dorongan dari } \\
\text { pemerintah untuk konversi } \\
\text { negara menjadi negara asal } \\
\text { impor, dan pengurangan pajak } \\
\text { PPh21. }\end{array}$ \\
\hline $\mathrm{O} 2$ & $\begin{array}{l}\text { Ketersedian Bahan } \\
\text { Baku }\end{array}$ & 0.16 & 3.00 & 0.48 & $\begin{array}{l}\text { Bahan baku selalu tersedia } \\
\text { dikarenakan kekayaan sumber } \\
\text { daya alam di Indonesia sebagai } \\
\text { salah satu negara yang } \\
\text { mempunyai hasil hutan yang } \\
\text { sangat besar }\end{array}$ \\
\hline $\mathrm{O} 3$ & $\begin{array}{l}\text { Perubahan Perilaku } \\
\text { Masyarakat }\end{array}$ & 0.18 & 3.00 & $0.54^{*}$ & $\begin{array}{l}\text { Kebijkan pemerintah pada masa } \\
\text { pandemi menimbulkan } \\
\text { permintaan baru bagi } \\
\text { ketersediaan masker khususnya } \\
\text { masker } N 95 \text {. }\end{array}$ \\
\hline & Sub Total & 0.50 & & 1.50 & \\
\hline \multicolumn{6}{|c|}{ THREATS } \\
\hline T1 & $\begin{array}{l}\text { Kondisi Resesi } \\
\text { Ekonomi }\end{array}$ & 0.16 & 3.25 & 0.52 & $\begin{array}{l}\text { Pada Triwulan IV } 2020 \text {, menteri } \\
\text { Keuangan Indonesia } \\
\text { mengumumkan bahwa Indonesia } \\
\text { berada pada kondisi resesi } \\
\text { ekonomi setelah data BPS } \\
\text { menunjukkan pertumbuhan } \\
\text { negara minus pada } 3 \text { periode di } \\
\text { tahun } 2020 \text { yoy. }\end{array}$ \\
\hline T2 & $\begin{array}{l}\text { Penurunan } \\
\text { Permintaan Kertas }\end{array}$ & 0.17 & 3.50 & $0.60^{*}$ & $\begin{array}{l}\text { Kebijakan pemerintah dalam } \\
\text { menanggulangi penyebaran } \\
\text { Covid-19 seperti kebijakan } \\
\text { bekerja dari rumah dan belajar } \\
\text { dari rumah menurunkan } \\
\text { permintaan kertas secara umum }\end{array}$ \\
\hline T3 & Adaptasi Teknologi & 0.17 & 3.25 & 0.55 & $\begin{array}{l}\text { Kebijakan pemerintah untuk } \\
\text { bekerja dan belajar di rumah juga } \\
\text { mendorong adaptasi telknologi } \\
\text { yang menyebabkan pemakaian } \\
\text { teknologi meningkat yang } \\
\text { menjadi substitusi dari kertas }\end{array}$ \\
\hline & Sub Total & 0.50 & & 1.67 & \\
\hline & GRAND TOTAL & 1.00 & & 3.17 & \\
\hline
\end{tabular}

From the EFAS table above, it can be seen that external factors that become opportunities for INKP are changes in community behavior with a weight score of 0.54 points. And the threat for INKP is a decrease in paper demand with a weight score of 0.60 points.

\section{TOWS Matrix and SWOT Cartesian Diagram}

After identifying and clarifying using SWOT analysis and IFAS and EFAS tables along with their weighting, the TOWS matrix can then be formulated to create alternative strategies by combining each of the factors, namely the SO (Strengths-Opportunities) strategy, WO (Weaknesses-Opportunities) strategy, ST strategy (Strengths-Threats), and WT (WeaknessesThreats) strategies.

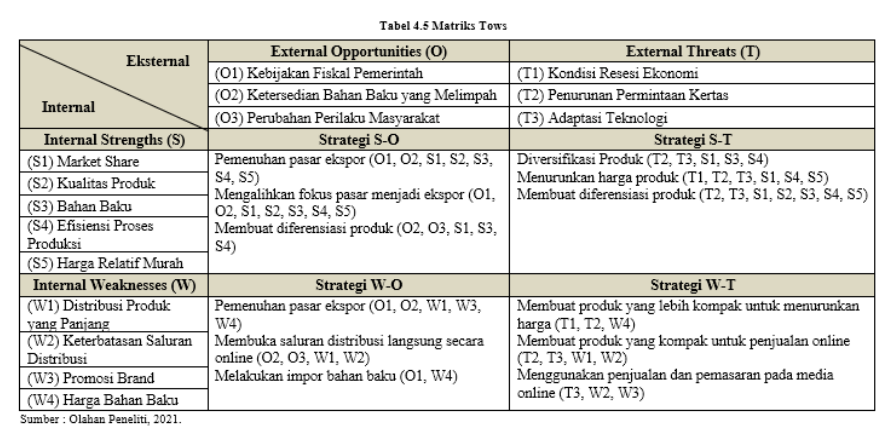

\section{Cartesian SWOT chart}

Assessment of internal and external factors in the IFAS and EFAS tables can be used to determine the main strategy for INKP. The difference in the weight score from the IFAS table between the strength and weakness factors is (+) 0.11 and the difference in the weight score from the EFAS table between the opportunity and threat factors is (-) 0.17 . The difference in these scores can be entered into a SWOT Cartesian diagram where the strength factor is positive $(+)$ and the opportunity and threat factors are negative (-).

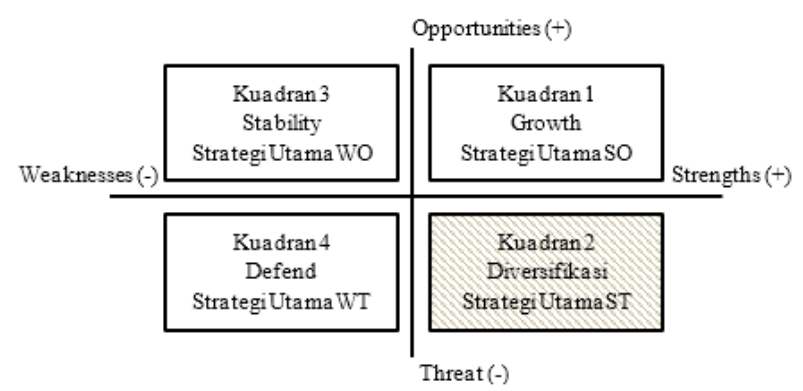

In the analysis of the company's internal conditions, it was found that the company's main strength is a highly efficient and integrated production process from the main raw materials to the final paper product. Quality is also a strength that comes from a good production process. The company's weakness is the distribution channel is quite long due to the geographical location of the factory which is far from the regional location of demand and target market. Promotion and choice of distribution channels are also weak due to market focus on big players and offices so that Brand Awareness of the products sold is low. 
Based on this analysis, a new goal was formulated for INKP to be able to maintain sales and increase profits, namely by diversifying products in the form of viscose rayon fiber with the final product of masks from pulp in 1 year and shifting production from $56 \%$ paper and $43 \%$ pulp to $45 \%$ paper, $34 \%$ pulp, and $20 \%$ rayon fiber in 3 years to maintain sales value and increase profit.

In formulating the strategy at the corporate level, one of the growth strategies was chosen with product diversification where product diversification still has linkages with existing products. This diversified product is rayon fiber which has the same raw material as paper, namely wood fiber / pulp. For the business-level strategy, it was found that INKP will compete with other companies in the industry by highlighting the uniqueness of its products. Using Porter's Generic Strategy Matrix, it was found that the product has advantages based on its uniqueness with a very broad target market so that the strategy that can be used is product differentiation. The products that will be marketed through this strategy are final products or consumer products in the form of masks where the masks produced by INKP have a uniqueness because they are produced from semisynthetic fiber raw materials that can be decomposed by nature naturally. Competitor products in the market still use petrochemical derivative products, namely polypropylene which cannot be decomposed naturally in nature.

In economic analysis and financial projections, CAPM is obtained with a value of 0.0708 . This value is positive which indicates the rate of return on investment is also positive.

\section{Cost of Equiy $=\mathrm{Rf}+\boldsymbol{\beta} \times(\mathrm{Rm}-\mathrm{Rf})$}

$$
\begin{aligned}
& \mathrm{Rf}=3.50 \%(\text { BI Rate pada May 2021) } \\
& \mathrm{Rm}=5.4072 \% \\
& \beta=1.8789
\end{aligned}
$$

\section{Cost of Equity $=0.0708$ atau 7,08 \%}

In the NPV analysis using a $7.08 \%$ cost of equity, the results of the calculation of the Net Present Value of Rp. 1,994,678,612,482 of capital investment. With a positive NPV value, it can indicate that the investment made has a greater income in the future so that investment can be recommended to be made.

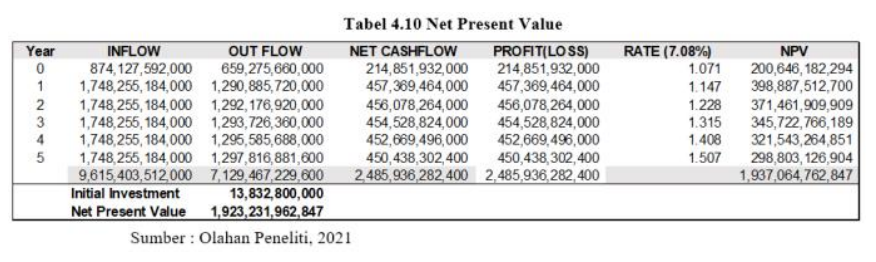

For IRR, the value is $39.87 \%$ where this investment has a return rate of $39.87 \%$. This value is better than

\begin{tabular}{|c|c|c|}
\hline \multicolumn{3}{|l|}{ Internal Rate of Return } \\
\hline Tingkat Bunga Rendah (rk) & & $7.08 \%$ \\
\hline Tingkat Bunga T inggi $(\mathrm{rb})$ & & $11.0 \%$ \\
\hline NPV - T ingkat Bunga Rendah (NPV rk) & $\mathrm{Rp}$ & $1,923,231,962,847$ \\
\hline Total Present Value Tingkat Bunga Rendah (TPV rk) & $\mathrm{Rp}$ & $1,937,064,762,847$ \\
\hline Total Present Value Tingkat Bunga Tinggi (TPV rb) & $\mathrm{Rp}$ & $1,707,124,351,383$ \\
\hline IRR & & $39.87 \%$ \\
\hline
\end{tabular}
the interest rate of $7.08 \%$ to $11 \%$ so the investment can be recommended.

Investments in rayon fiber production lines and masks can be made in one project that is planned to be implemented in 1 year. The activities carried out are:
a. Rayon Fiber Factory Facility Planning
b. Factory Facility Construction
c. Human Resources Preparation
d. Start-up Process

After the stages of the process, the product is expected to be marketed in accordance with the marketing plan and market demand. The planned marketing activities include:
a. Product Research and Market Analysis
b. Marketing Strategy Planning
c. Marketing Activities
d. After Sales Service or After Sales Service

All production processes and marketing activities can be evaluated through performance appraisal activities 
with targets and performance indexes that have been determined in accordance with the function of the activity. For overall, evaluation can be done through EBIT and EBITDA which are one of the references for assessing a company's income before tax, interest, depreciation, and amortization.

\section{CONCLUSION}

The conclusions obtained from the research conducted are:

\section{Company External Conditions}

In 2020, Indonesia was also affected by the Covid-19 pandemic. Indonesia's economic growth rate fell by $2.19 \%$ yoy in 2020 which is one indicator of a decline in economic activity such as reduced employment, average income, investment and public spending. People tend to buy basic needs compared to other expenditures in the current economic conditions. Socially, people are asked to adapt new habits so that changes in people's behavior. Offices adopted work from home and began to adapt technology which was also followed by a decline in the demand for paper in offices. On the other hand, the government implements fiscal policy in changing the country into a country of origin of imports by implementing import tax relaxation and providing incentives to companies

\section{Company Internal Condition}

INKP has its main strength, namely a highly efficient and integrated production process from the main raw materials to the final paper product. Quality is also a strength that comes from a good production process. The company's weakness is the distribution channel is quite long due to the geographical location of the factory which is far from the regional location of demand and target market. Promotion and choice of distribution channels are also weak due to market focus on big players and offices so that Brand
Awareness of the products sold is low when office activity declines.

Based on the SWOT analysis, it was found that in the BCG matrix, INKP is in quadrant 2, namely cash cow where the company has a relatively high competitive position with a low market growth rate. In the Internal External Matrix, quadrant 7 is found with the recommended strategy, namely growth: concentric diversification. This was obtained after knowing the high internal strength of INKP's business and the declining attractiveness of the paper industry. And on the Cartesian diagram, after plotting the results of EFAS and IFAS, it is found that the main strategy suggested is diversification or the main strategy of ST, which is to use internal strength to minimize external threats, where one of the ST strategies is product diversification.

\section{Formulation of Objectives based on the Company's Current Conditions}

Based on this analysis, a new goal was formulated for INKP to be able to maintain sales and increase profits, namely by diversifying products in the form of viscose rayon fiber with the final product of masks from pulp in 1 year and shifting production from $56 \%$ paper and $43 \%$ pulp to $45 \%$ paper, $34 \%$ pulp, and $20 \%$ rayon fiber in 3 years to maintain sales value and increase profit.

\section{Strategy}

In formulating the strategy at the corporate level, one of the growth strategies was chosen with product diversification where product diversification still has linkages with existing products. This diversified product is rayon fiber which has the same raw material as paper, namely wood fiber / pulp. For the business-level strategy, it was found that INKP will compete with other companies in the industry by highlighting the uniqueness of its products. 
Using Porter's Generic Strategy Matrix, it was found that the product has advantages based on its uniqueness with a very broad target market so that the strategy that can be used is product differentiation. The products that will be marketed through this strategy are final products or consumer products in the form of masks where the masks produced by INKP have a uniqueness because they are produced from semi-synthetic fiber raw materials that can be decomposed by nature naturally.

\section{Tactics}

In implementing a corporate-level strategy using diversified products, investment is needed to build the Rayon Fiber product line and masks from the rayon fiber. In the economic analysis for rayon fiber and masks from rayon fiber, positive NPV values were obtained for both products so that it can be concluded that the investment is worth making.

\section{Actions}

Investments in rayon fiber production lines and masks can be made in one project that is planned to be implemented in 1 year. The activities carried out are:
a. Rayon Fiber Factory Facility Planning
b. Factory Facility Construction
c. Human Resources Preparation
d. Start-up Process

After the stages of the process, the product is expected to be marketed in accordance with the marketing plan and market demand. The planned marketing activities include:
a. Product Research and Market Analysis
b. Marketing Strategy Planning
c. Marketing Activities
d. After Sales Service or After Sales Service

\section{Control and Evaluation}

The control and evaluation of the profitability of product diversification can be seen from the company's EBITDA calculation. This EBITDA is the estuary of the performance index and targets of each line that supports production and sales.

\section{REFERENCES}

[1]. Ade Permata Surya. (2018). Customer Loyalty From Perspective of Marketing Mix Strategy and Customer Satisfaction A Study from Grab Online Transportation in Era of Industrial Revolution 4.0. Jurnal Ilmiah Manajemen, Volume 9, No. 3, Oktober 2019 Surya $394-406$ ISSN : 2088-1231 E-ISSN: 2460-5328 DOI: dx.doi.org/10.22441/mix.2019.v9i3.001

[2]. Alma, B. (2011). Manajemen Pemasaran dan Pemasaran Jasa. Bandung: Alfabeta.

[3]. Amalia, Aisyah. 2016. Perencanaan Strategi Pemasaran Dengan Pendekatan Bauran Pemasaran dan SWOT Pada Perusahaan Popsy Tubby. Jurnal Manajemen dan Start-Up Bisnis Volume 1, Nomor 3, Agustus 2016

[4]. Badan Pengkajian dan Pengembangan Perdagangan, (2016) Warta Pengkajian Perdagangan, Volume III. No. 12, Tahun 2016

[5]. Cahyono, Puguh. (2016). Implementasi Strategi Pemasaran Dengan Menggunakan Metode SWOT Dalam Upaya Meningkatkan Penjualan Produk Jasa Asuransi Kecelakaan dan Kematian Pada PT. Prudential Cabang Lamongan. Jurnal Penelitian Ilmu Manajemen Volume I No.02, Februari 2016 ISSN : 2502-3780.

[6]. Citra, T., \& Santoso, S., B., (2016), Analisis Pengaruh Kualitas Produk dan Citra Merek Terhadap Keputusan Pembelian Cetakan Continuous Form Melalui Kepercayaan Merek (Studi Pada Percetakan Jadi Jaya Group, Semarang), Jurnal Studi Manajemen \& Organisasi 13 (2016) Juni 67-79. 
Gery Azhari Putera et al Int J Sci Res Sci \& Technol. November-December-2021, 8 (6) : 252-271

[7]. Ganiyu, e. a. (2012). Is Customer Satisfaction an Indicator of Customer Loyalty? Australian Journal of Business and Management Research, Vol.2 (No.07), [14-20].

[8]. Gillespia. (2007). Foundations of Economics Additional chapter on the Business Strategy, PESTLE analysis of the macro-environment, Oxford University Press

[9]. Hudaya, A., (2020), Analisa Faktor yang Mempengaruhi Niat Pembelian Kembali Pada Private Label, Jurnal Ilmiah Manajemen Bisnis, Volume 6, No. 01, Maret 2020 59-76

[10]. Indriyani, Eka. (2017), Pengaruh Ukuran Perusahaan Dan Profitabilitas Terhadap Nilai Perusahaan, Akuntabilitas: Jurnal Ilmu Akuntansi Volume 10 (2).

[11]. Keller, K., (2013), Strategic Brand Management: Building, Measuring, and Managing Brand Equity Global Fourth Edition, England: Pearson Education Limited.

[12]. Kotler P., \& Keller KL., (2012), Marketing Management: Edition 14, New Jersey: Pearson Education, Inc.

[13]. Kotler Philip. 2006, Marketing Management Millenium, Edition Prentice Hall International New Jersey.

[14]. Kotler Philiph and Keller, 2009, Marketing : An Introduction, Fourth Ed, Prentice Hall, Canada.

[15]. Kotler, P. \& Armstrong, G. (2006), Prinsipprinsip Pemasaran (Bob Sabran, Penerjemah), Jakarta: Penerbit Erlangga

[16]. Kotler, Philip dan Amstrong Gery. 2004. Prinsip-prinsip Pemasaran. Jakarta: PT.Malanan Jaya Cermelang.

[17]. Kussuma, P., Surachman, A., \& Tanuatmodjo, H., (2016), Dampak Tingkat Profitabilitas Dan Nilai Pasar Pada Pergerakan Harga Saham PT. Prasidha Aneka Niaga Tbk, Journal of Business Management Education Volume 1, Number 2, August 2016, 97-103.

[18]. Laporan Keuangan Kuartal 12020 PT. Indah Kiat Pulp \& Paper Tbk., (2020), 10 Desember
2020 https://idnfinancials.s3-ap-southeast1.amazonaws.com/financialstatements/INKP/2020/1Q 2020_INKP_Indah+ Kiat+Pulp+\%26+Paper+Tbk.pdf

[19]. Laporan Keuangan Kuartal 22020 PT. Indah Kiat Pulp \& Paper Tbk., (2020), 10 Desember 2020

https://emiten.kontan.co.id/download/0yNO88f 8HJEWI-

Wi1KmgYxy9M0R8iEbAdN091xHFWXo

[20]. Laporan Keuangan Kuartal 32020 PT. Indah Kiat Pulp \& Paper Tbk., (2020), 10 Desember 2020

https://www.idx.co.id/Portals/0/StaticData/Liste dCompanies/Corporate_Actions/New_Info_JSX/ Jenis_Informasi/01_Laporan_Keuangan/02_Soft _Copy_Laporan_Keuangan//Laporan\%20Keuan gan\%20Tahun\%202020/TW3/INKP/IKPP\%20R eport-

Billingual\%2030\%20September\%202020.pdf

[21]. Laporan Tahunan - Annual Report 2019 PT. Indah Kiat Pulp \& Paper Tbk, (2019), 10 Desember 2020 https://asiapulppaper.com/documents/20123/15 0293/INKP+-+Annual+Report+2019.pdf/

[22]. Lembaga Pengembangan Bisnis dan Inkubasi Universitas Airlangga, (2018), Analisa Rantai Pasok (Supply Chain) Komoditas Unggulan Ekspor Indonesia : Pulp \& Kertas.

[23]. Lovelock, Wirtz. (2011). Services Marketing (People, Technology, Strategy). Pearson Education Limited. England

[24]. Malau, H. (2017). Manajemen Pemasaran: Teori dan Aplikasi Pemasaran Era Tradisional Sampai Era Modernisasi Global. Bandung: Alfabeta.

[25]. Maleki, S., Aghdaie, SFA., Shahin A., \& Ansari, A., (2020), Investigating the Relationship Among the Kansei-Based Design of Chocolate Packaging, Consumer Perception, and Willingness To Buy, Journal Of Marketing Communications 2020, Vol. 26, No. 8, 836-855, 
https://Doi.Org/10.1080/13527266.2019.159085 5.

[26]. Meliana, Y., \& Simanjuntak, S., (2012), Faktor Yang Mempengaruhi Minat Beli Produk Makanan dan Minuman Usaha Kecil Menengah Kabupaten Tangerang, Jurnal Manajemen dan Kewirausahaan, Vol.14, No. 2, September 2012: 164-172.

[27]. Noor, Syamsudin. 2014. Penerapan Analisis SWOT Dalam Menentukan Strategi Pemasaran Daihatsu Luxio Di Malang (Studi Kasus Pada Pt. Astra International Tbk. - Daihatsu Malang). Jurnal INTEKNA, Tahun XIV, No. 2, Nopember $2014: 102-209$.

[28]. Novianti, N., Endri, E., \& Darlius, D. (2018). Kepuasan Pelanggan Memediasi Pengaruh Kualitas Pelayanan Dan Promosi Terhadap Loyalitas Pelanggan. Mix: Jurnal Ilmiah Manajemen, $\quad 8(1)$, 90. doi:10.22441/mix.2018.v8i1.006

[29]. Nuraini, Aji, ST., \& Anah, L., (2020), Pengaruh Promosi dan Kualitas Produk Terhadap Minat Beli Kerudung Rabbani (Studi Kasus Pada Pondok Pesantren Putri Waisongo Cukir Jombang), Jurnal Ilmiah Manajemen Bisnis, Volume 6, No. 02, Juni 2020 165-173

[30]. Pardede, R., \& Haryadi, TY., (2017), Pengaruh Persepsi Harga dan Kualitas Produk Terhadap Keputusan Pembelian Konsumen Yang Dimediasi Kepuasan Konsumen, Journal of Business \& Applied Management Vol. 10 No. 1 55-79.

[31]. Qalati SA, Yuan LW, Iqbal S, Hussain RY, \& Ali S., (2019), Impact of Price on Customer Satisfaction; mediating role of Consumer Buying Behaviour in Telecom Sector. Journal of Research 6: 150-165. https://journals.pen2print.org/index.php/ijr/

[32]. Rangkuti, F., (2005), Business Plan Teknik Membuat Perencanaan Bisnis dan Analisis Kasus, Jakarta: PT. Gramedia Pustaka Utama.
[33]. Rastogi, N and Trivedi, M.K. (2016). Technique - A Tool To Identify External Risks In Construction Projects International Research Journal of Engineering and Technology (IRJET) e-ISSN: 2395-0056 Volume: 03 Issue: 01 Jan2016 www.irjet.net p-ISSN: 2395-0072

[34]. Retnowati, N., D., (2011), Analisis CSF, SWOT dan TOWS Studi Kasus: PT Intan Pariwara Klaten, Jurnal Buana Informatika, Volume 2, Nomor 1, Januari 2011: 31-37.

[35]. Rice, A., (2016), Analisa Faktor-Faktor Yang Mempengaruhi Pertumbuhan Laba Dengan Ukuran Perusahaan Sebagai Variabel Moderating Pada Perusahaan Manufaktur Yang Terdaftar Di Bursa Efek Indonesia, Jurnal Wira Ekonomi Mikroskil Volume 6, Nomor 01, April 2016 86-101.

[36]. Sari, V., A., (2017), Pengaruh Harga, Kualitas Produk dan Citra Merek Terhadap Keputusan Pembelian Teh Siap Minum Dalam Kemasan Teh Botol Sosro, Diponegoro University Journal Of Social And Politic, Business Administration 2017.

[37]. Sekaran, U., (2006), Metode Penelitian Bisnis, Jakarta: Salemba Empat.

[38]. Setyorini, H., Effendi, M., dan Santoso, I. Analisis Strategi Pemasaran Menggunakan Matriks SWOT dan QSPM (Studi Kasus: Restoran WS Soekarno Hatta Malang). Jurnal Teknologi dan Manajemen Agroindustri Volume 5 Nomor 1: 46-53.

[39]. Shinta, A., (2011), Manajemen Pemasaran, Malang: UB Press.

[40]. Sidharta, RBFI,. Sari, NLA., \& Suwandha, W., (2018), Purchase Intention Pada Produk Bank Syariah Ditinjau dari Brand Awareness dan Brand Image dengan Trust Sebagai Variabel Mediasi, Jurnal Ilmiah Manajemen, Volume 8, No. 3, Oktober 2018 562-678.

[41]. Siyoto, S., \& Sodik, A., (2015), Dasar Metodologi Penelitian, Yogyakarta: Literasi Media Publishing. 
[42]. Stephani, SB., \& Nashar, M., (2020), Pengaruh Harga, Citra Merek Dan Kualitas Layanan Terhadap Keputusan Pembelian Produk Online Jakmall, Jurnal Ilmiah Manajemen Bisnis, Volume 6, No. 1, Maret 2020 125-144.

[43]. Suryana, P., \& Dasuki, E., S., (2013), Analisis Faktor Yang Mempengaruhi Keputusan Pembelian dan Implikasinya Pada Minat Beli Ulang, Trikonomika Volume 12, No. 2, Desember 2013, Hal. 190-200.

[44]. Susanti, V., Sumarwan, U., Simanjuntak, M., \& Yusuf, E., (2019), Pengaruh Perceived Brand Quality, Perceived Value dan Switching Cost Terhadap Customer Satisfaction dan Brand Loyalty: Studi Pasar Industri Kimia di Indonesia, Jurnal Ilmiah Manajemen, Volume 9, No. 2, Juni 2019 282-297.

[45]. Tjiptono, Fandy. 2004. Perspektif Manajemen dan Pemasaran Kontemporer. Yogyakarta : Andi.

[46]. Yudaruddin, R. (2019), Forecasting: Untuk Kegiatan Ekonomi dan Bisnis, Samarinda: RV Pustaka Horizon.

[47]. Zia, HK., Semiarty, R., dan Lita, RP. Analisis SWOT Sebagai Penentu Strategi Pemasaran Pada Rumah Sakit Gigi dan Mulut Baiturrahmah Padang. Jurnal Kesehatan Andalas. 2018; 7 (Supplement 4).

\section{Cite this article as :}

Gery Azhari Putera, Jerry Heikal, "Business Strategy of Indah Kiat Pulp and Paper Perawang Mill, Riau, Indonesia using PESTLE, Porter's Five Forces, and SWOT Analysis under SOSTAC® Framework", International Journal of Scientific Research in Science and Technology (IJSRST), Online ISSN : 2395-602X, Print ISSN : 2395-6011, Volume 8 Issue 6, pp. 252-271, November-December 2021. Available at doi : https://doi.org/10.32628/IJSRST218624 Journal URL : https://ijsrst.com/IJSRST218624 